\title{
Assessment of Stand-Alone Residential Solar Photovoltaic Application in Sub-Saharan Africa: A Case Study of Gambia
}

\author{
Sambu Kanteh Sakiliba, ${ }^{1}$ Abubakar Sani Hassan, ${ }^{1}$ Jianzhong Wu, \\ Edward Saja Sanneh, ${ }^{2}$ and Sul Ademi ${ }^{3}$ \\ ${ }^{1}$ Institute of Energy, Cardiff University, Queen's Buildings, The Parade, Cardiff CF24 3AA, UK \\ ${ }^{2}$ Ministry of Energy, Banjul, Gambia \\ ${ }^{3}$ Institute for Energy and Environment, Department of Electronic \& Electrical Engineering, University of Strathclyde, \\ Technology and Innovation Centre, Level 4, 99 George Street, Glasgow G1 1RD, UK
}

Correspondence should be addressed to Sambu Kanteh Sakiliba; sambuks@cardiff.ac.uk

Received 1 August 2015; Revised 14 October 2015; Accepted 18 October 2015

Academic Editor: Yongsheng Chen

\begin{abstract}
Copyright (C) 2015 Sambu Kanteh Sakiliba et al. This is an open access article distributed under the Creative Commons Attribution License, which permits unrestricted use, distribution, and reproduction in any medium, provided the original work is properly cited.

The focus of this paper is the design and implementation of solar PV deployment option, which is economical and easy to maintain for remote locations in less developed countries in Sub-Saharan Africa. The feasibility of stand-alone solar PV systems as a solution to the unstable electricity supply and as an alternative to the conventional resource, "diesel generators," is presented. Moreover, a design of a system is carried out, such that the electrical demand and site meteorological data of a typical household in the capital, Banjul, is simulated. Likewise, the life cycle cost analysis to assess the economic viability of the system, along with the solar home performance, is also presented. Such system will be beneficial to the inhabitants of Gambia by ensuring savings in fuel costs and by reducing carbon emissions produced by generators. The selection of appropriate-sized components is crucial, as they affect the lifetime, reliability, and initial costs. The design presented in this study represents a solution for domestic houses to adopt the system according to the location and environment, in order to meet electricity demand.
\end{abstract}

\section{Introduction}

In relation to the progress of a country, electricity is one of the elements required for agricultural, commercial, industrial, or residential development. In most countries of the world, areas with no electricity are less developed than those with electricity. The use of photovoltaics (PV) to produce electricity from sunlight would strongly benefit and improve the quality of life for those less developed countries such as Gambia. Closer studies would demonstrate that the energy sector in Sub-Saharan Africa can offer opportunities for implementing ambitious renewable energy (RE) programs. The decentralized approach based on power produced with locally available renewable energy resources is, for various reasons, gradually being recognized as a viable alternative in remote places of Gambia. This African country is making a considerable effort to provide electricity to rural and urban households generated from fossil fuel based resources, such as fuelwood and liquefied petroleum gas (LPG), although it has been a slow and ineffective process for many years [1]. Part of the population, including the capital Banjul, have no access to affordable energy resources with households living in situations where sometimes the electricity is unstable. Since 2007, power outages occur almost every day in Gambia, with an average duration of 6.86 hours [2].

Over the last few decades Gambia has witnessed a rapid increase in its population, infrastructure, and business expansion, triggering a rise in demand in the generation and transmission of electricity. Due to the poor state of transmission and distribution networks, the magnitude of the demand has exceedingly outstretched the available installed capacity, thus, culminating in the reoccurrence of frequent maintenance intervals and continuous load shedding [3]. Consequently, the historical and current billed electricity demand figures cannot reflect the actual requirements of the National Water and Electricity Company (NAWEC) customers, which has 
been under the management of the President's office since 2002. In Gambia regular power cuts have occurred since 1977 following the Sahelian drought; since then, the demand for electricity and water has increased. Over the past thirty years utility corporations have suffered mechanical breakdowns in the energy sector, with frequent power outages $[2,3]$. Furthermore, businesses and hotels use generators; nevertheless, these are not financially sustainable due to the high cost of fuel [4]. The price of petrol and diesel in Gambia increased between February and April of 2013 from $£ 0.72 / 1$ to $£ 0.79 / 1$ for diesel and from $£ 0.75$ to $£ 0.83 / 1$ for petrol, and it is expected to continue to rise in the future [5]. The daily average solar energy potential in the capital is $5.7 \mathrm{kWh} / \mathrm{m}^{2}$ [6]; therefore, an alternative energy source such as solar PV systems could be a cost-effective alternative for households and allow their electricity requirements to be met, instead of using diesel generators.

In this paper, a method for the design of an alternative stand-alone solar PV system adoption option for Gambia was developed. The method was used to design and size a standalone system that will be economically competitive when compared to purchasing electricity from the utility grid.

The rest of the paper is organized as follows. Section 2 introduces Gambia as a country. Section 3 reviews the potential of the country's solar energy resource. Section 4 presents the typical building model for households in Banjul, the country's capital. Section 5 presents the model of the solar PV configuration of a typical solar PV system in Gambia [1]. Section 6 presents the methodology used for the stand-alone solar PV design, sizing, and simulation. Section 7 presents the results and discussion, and Section 8 represents the economic analysis of the system designed in Section 6.

\section{Gambia}

Gambia is situated on the Atlantic coast in West Africa surrounded by Senegal (Figure 1), and the capital is Banjul, located at latitude $13.2^{\circ}$ north and longitude $16.6^{\circ}$ of the equator. The country has a hot, tropical climate with a rainy season from June to November. The country's economy concentrates on tourism, farming, and fishing with a third of the population living under the international poverty line on $£ 0.75 /$ day [7].

2.1. Energy and Electricity Sector of Gambia. At the end of 2000, the energy consumption was 0.26 tonnes of oil per capita (TOE), which was supplied by $77 \%$ of firewood, $21 \%$ of petroleum products, and 2\% of electricity (Figures 2 and 3). The principal consumers at this time were households and the transportation sector, with a percentage of $83 \%$ and $13 \%$, respectively $[2,3]$. NAWEC reported an electricity consumption of $80 \mathrm{GWh}$ in 2002 with households being the major consumers facing extremely high electricity costs. As a result, many households struggled to pay electricity bills, due to the high price of the tariff. At that time, the tariff ranges were from $£ 0.11 / \mathrm{kWh}$ to $£ 0.15 / \mathrm{kWh}$ [3], and the capital, Banjul, was supplied by diesel generators with a total capacity of $44 \mathrm{MW}$. In Gambia, the electricity sector

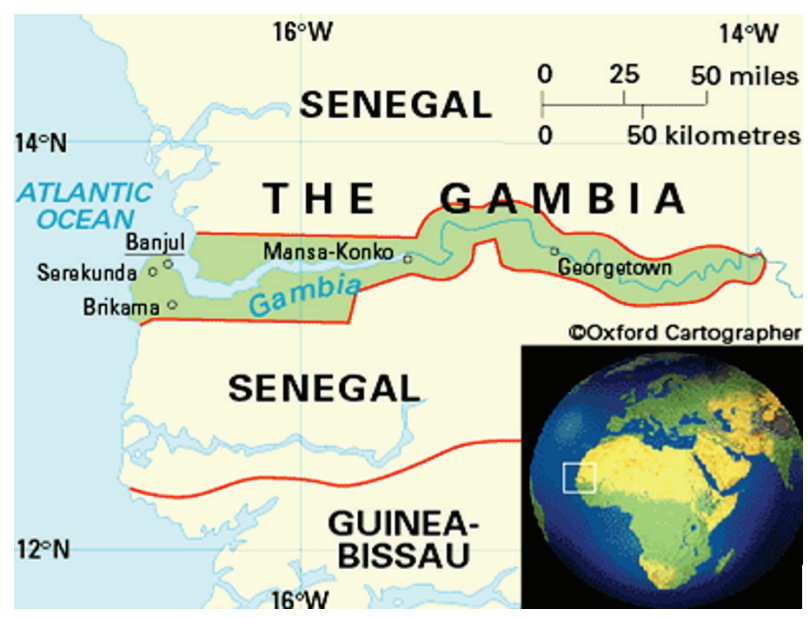

Figure 1: Map and location of Gambia [8].

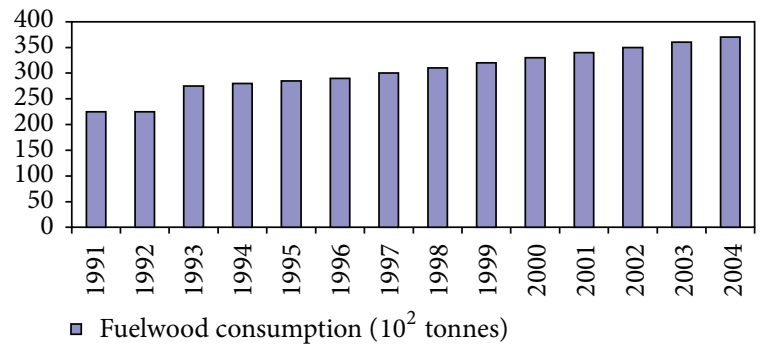

FIgURE 2: Fuelwood consumption from 1991 to 2004 [9].

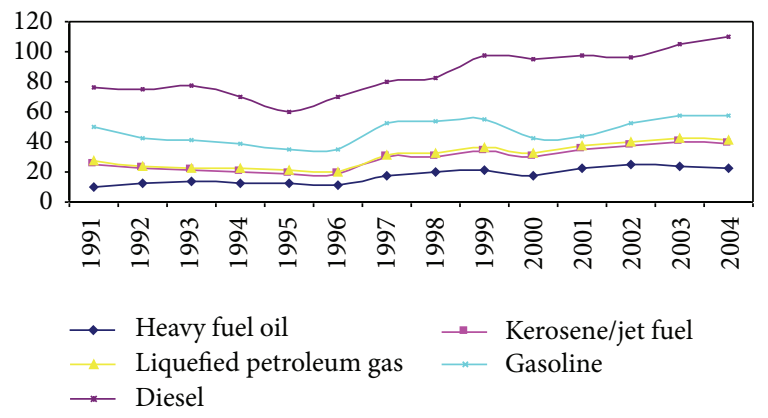

FIGURE 3: Petroleum consumption ( $10^{2}$ tonnes) from 1991 to 2004 [9].

is presently facing serious issues and is unable to meet the demand. The transmission and distribution system is poor with technical and nontechnical losses requiring an improvement in efficiency, in order to reduce the high energy costs [6].

2.2. Household Demand. Most households in Gambia have no access to energy services. In 2005, 64\% of urban users were connected to the grid [10], where six provincial centres were electrified with diesel fired isolated systems with a total capacity of $11 \mathrm{MW}$ of electricity to supply, available for 15 hours on average $[3,10]$. For lighting, other processes, for instance, kerosene or candles, can be used; nevertheless, these 


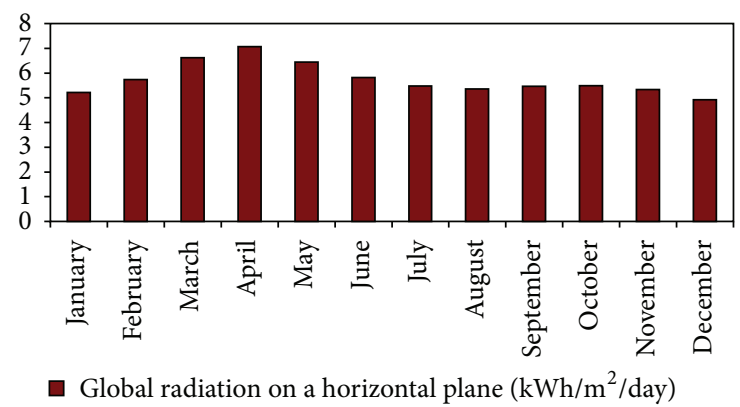

FIGURE 4: Monthly average daily global radiation.

methods are dangerous and reasonably inefficient. Therefore, stand-alone solar PV systems (SSPVS) in homes are perceived to be an excellent alternative to supply power to a population in need of solutions.

\section{The Potential of Solar Energy}

The energy sector in the country is facing difficulties leading to financial restrictions for the foreseeable future, due to its importation of fuel and a fragile supply. Gambia has considerable RE resource such as solar energy. The country benefits from high solar radiation all year round with an average of 4.5 to $6.7 \mathrm{kWh} / \mathrm{m}^{2} /$ day (Figure 4 ). Despite the rainy season (June to November) the country receives abundant amounts of solar radiation at about $5 \mathrm{kWh} / \mathrm{m}^{2} /$ day. At the moment, many SSPVS are in use across the country for many purposes such as electrification and water pumping in rural and urban areas. Most of the projects have been funded by the government and donors to provide energy in public services such as hospitals and schools and for street lighting.

\section{Representation of a 3D Building Model}

The goal of the 3D modelling as demonstrated in Figure 5 is to visualize the state of the art of a typical urban domestic dwelling in Banjul. The 3D model has also considered the domestic dwelling construction properties as well as the implemented renewable energy technology to provide electricity. The building was modelled using the graphical user interface Sketchup Pro 8 [11]. The domestic dwelling is southoriented and is composed of a lounge, kitchen, dining room, three bedrooms, bathroom, electrical equipment room, and the SSPVS components room.

\section{Household Solar PV System Configuration}

The configuration for a SSPVS (Figure 6) was considered in this paper from a pilot study conducted in 2009 to evaluate the suitability of solar PV usage in urban communities [1]. The system consisted of three PV modules, inverter, battery bank, and load. The function of the PV panels is to convert sunlight into DC electrical power. The inverter is used to convert the DC electrical input power into AC output power to be supplied to the appliances. The battery bank stores

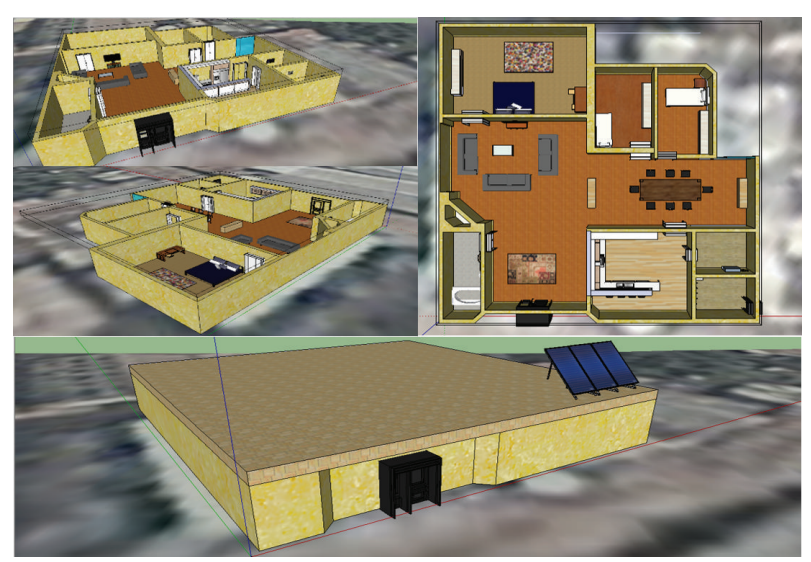

FIgURE 5: Three-dimensional model and representation of a typical urban house in Banjul.

the excess DC power to be used when there is no sunshine. The controller monitors the electrical input generated from the solar panels, the amount entering the inverter, and the quantity of electrical energy for charging and discharging the battery bank.

\section{Methodology}

6.1. Stand-Alone Solar Photovoltaic System Design. The meteorological and environmental data was collected from the Photovoltaic Geographical Information System (PVGis) of the Joint Research Centre (JRC), Institute of Energy and Transports European Commission, to predict the performance of the SSPVS. Banjul's monthly average daily solar radiation incident on the horizontal surface is very high, especially in April, where radiation reaches $7.07 \mathrm{kWh} / \mathrm{m}^{2} /$ day on the horizontal (Figure 4). The load profile is assumed to run for 24 hours a day during whole year, as the average daily power outage in Gambia is 6.86 [2]. Total energy consumed was calculated from Table 1 as $3.332 \mathrm{kWh} /$ day compensating previously the rated power $\left(P_{\text {rated }}\right)$ of each appliance. In order to accomplish an effective power compensation $\left(P_{i}\right), P_{\text {rated }}$ of each load has been divided by the adjustment factor. The adjustment factor is related to the efficiency of the inverter and reflects the actual power consumed from the battery bank to operate AC loads from the inverter [5]. For this application the adjustment factor is 0.90 .

The design criteria for the SSPVS were considered using the minimum average solar radiation in a month to determine the size of the PV array and battery bank and by investigating the daily demands to meet the resulting sizes. Banjul is located at $13.2^{\circ} \mathrm{N}$ latitude and $16.6^{\circ} \mathrm{E}$ longitude. Therefore, the angle of inclination of the PV array measured from the horizontal (tilt angle) is maximized with an angle of $41^{\circ}$ facing south, considering the less favourable season, winter:

$$
\text { Tilt angle: [(Latitude } * 0.9)+ \text { Season angle] }
$$

where (i) latitude is $13.2^{\circ} \mathrm{N}$ and (ii) winter seasonal angle is $29^{\circ}$. 
TABLE 1: Household load consumption data.

\begin{tabular}{|c|c|c|c|c|c|}
\hline Appliances & Quantity & $P_{\text {rated }}(\mathrm{kW})$ & $\begin{aligned} & P_{i}= P_{\text {rated }} / 0.90 \\
&(\mathrm{~kW})\end{aligned}$ & $\begin{array}{c}\text { Use } \\
\text { (H/day) }\end{array}$ & Energy (kWh/day) \\
\hline Lights & 6 & 0.008 & 0.088 & 4 & 0.352 \\
\hline Fridge & 1 & 0.300 & 0.333 & 6 & 1.998 \\
\hline Radios & 1 & 0.008 & 0.088 & 1 & 0.088 \\
\hline Computers & 1 & 0.250 & 0.277 & 2 & 0.554 \\
\hline TVs & 1 & 0.020 & 0.022 & 4 & 0.088 \\
\hline DVD & 1 & 0.010 & 0.011 & 2 & 0.022 \\
\hline Fans & 1 & 0.042 & 0.046 & 5 & 0.230 \\
\hline \multicolumn{2}{|c|}{ Total } & 0.678 & 0.865 & 24 & 3.332 \\
\hline
\end{tabular}

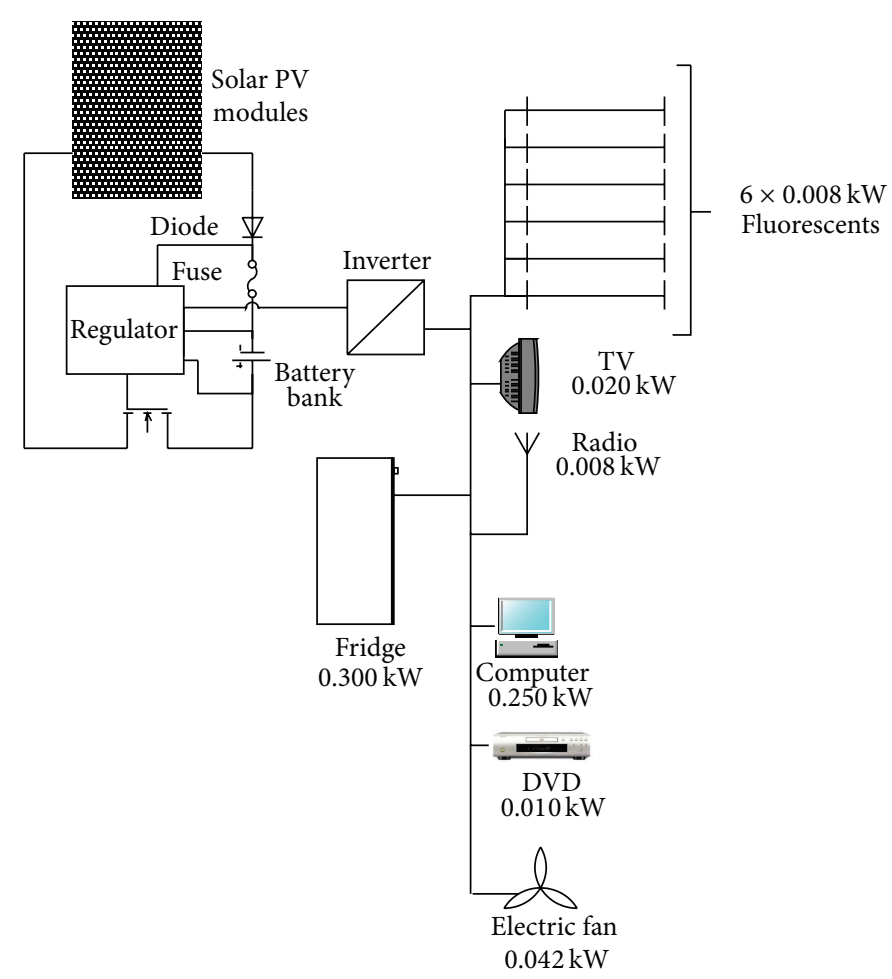

FIGURE 6: Ideal solar PV system for an urban Gambian home.

The PV array output is related to the intensity of light striking the panels, ambient and cell temperature, status of the loads, and characteristics of the PV array. The reason that the tilted angle was considered to be $41^{\circ}$ and facing south is because the panels will be directly facing the sun at mid-day during those short winter days, hence, being more effective during the summer.

The lifespan of a battery depends on the depth of discharge (DoD); thus, in this case and in accordance with the selected battery, a DoD of 0.5 was considered. Battery sizing is based on the power supply during 3 autonomous days $(N)$ [12]. The total power of the system is $0.865 \mathrm{~kW}\left(P_{i}\right)$ with a total energy consumed $\left(E_{d^{\prime}}\right)$ of $3.332 \mathrm{kWh}$ consequently (Table 1$)$; a DC system voltage of $24 \mathrm{~V}$ is suitable.
The current consumption by the load is $0.138 \mathrm{kAh}$, calculated by

$$
I_{d}=\frac{E_{d^{\prime}}}{\text { DC system voltage }}
$$

The selected battery is lead-acid vented tubular type, with a nominal voltage $\left(V_{n b}\right)$ of $12 \mathrm{~V}$, storage capacity $\left(C_{b}\right)$ of $239 \mathrm{Ah}$, temperature derating factor (D.F) of 0.8 for a temperature of $25^{\circ} \mathrm{C}$, and battery efficiency $(\mu)$ of $97 \%$ and without any maintenance required [12]. The battery bank is calculated 
below obtaining 2 batteries in series $\left(B_{\mathrm{s}}\right)$ and $3.46 \approx 3.5$ batteries in parallel $\left(B_{\mathrm{p}}\right)$ :

$$
\begin{aligned}
& B_{\mathrm{s}}=\frac{\text { DC Voltage system }}{V_{n b}} \\
& B_{\mathrm{p}}=\left(\frac{\left(\left(I_{d} * N\right) / \text { Dod }\right)}{C_{b}}\right) .
\end{aligned}
$$

In consequence, the total number of batteries $\left(B_{\mathrm{t}}\right)$ required is $6.92 \approx 7$ from the product of $(3)$ :

$$
B_{\mathrm{t}}=B_{\mathrm{s}} * B_{\mathrm{p}}
$$

The maximum radiation time selected is $4.92 \mathrm{kWh} / \mathrm{m}^{2} /$ day $\left(M_{\mathrm{rt}}\right)$ for the worst month of the year, which is December (Figure 4). Assuming a DC system voltage of $24 \mathrm{~V}$, a power of $0.275 \mathrm{~kW}_{\mathrm{p}}\left(P_{\text {panel }}\right)$, short-circuit current of $5.80 \mathrm{~A}\left(I_{\mathrm{psc}}\right)$, and rated voltage of $51.2 \mathrm{~V}\left(V_{\text {rated }}\right)$ from the panels and a $97 \%$ of battery efficiency $(\mu)$, the required output energy of the array $\left(E_{\mathrm{a}}\right)$ and output energy per module each day $\left(E_{\text {om }}\right)$ calculated in this study are $3.435 \mathrm{kWh}$ and $1.353 \mathrm{kWh}$, respectively, obtained by

$$
\begin{aligned}
E_{\mathrm{a}} & =\left(\frac{E_{d^{\prime}}}{\mu}\right) \\
E_{\mathrm{om}} & =P_{\text {panel }} * M_{\mathrm{rt}} .
\end{aligned}
$$

The energy output of the modules $\left(E_{\text {out }}\right)$ is related to the ambient temperature [13]. Energy temperature relationship influences the performance of the modules; hence, a D.F of 0.8 is justified for hot climates and critical applications such as Banjul [14]. Therefore, an energy output is obtained at an operating temperature of $1.082 \mathrm{kWh}$ from the modules by

$$
E_{\text {out }}=\mathrm{D} . \mathrm{F} * E_{\mathrm{om}} .
$$

In order to obtain the total number of modules $\left(M_{\mathrm{t}}\right)$, the PV panels in series $\left(M_{\mathrm{s}}\right)$ and parallel $\left(M_{\mathrm{p}}\right)$ are calculated priorly; therefore, the accomplished values are 0.48 and 6.34 , respectively, by

$$
\begin{aligned}
& M_{\mathrm{s}}=\left(\frac{\text { DC system voltage }}{\left(V_{\text {rated }} * \mu\right)}\right) \\
& M_{\mathrm{p}}=\left(\frac{\left(E_{\mathrm{a}} / E_{\text {out }}\right)}{M_{\mathrm{s}}}\right) .
\end{aligned}
$$

Thus, the total number of PV modules $\left(M_{\mathrm{t}}\right)$ is $3.04 \approx 3$, determined by

$$
M_{\mathrm{t}}=M_{\mathrm{s}} * M_{\mathrm{p}}
$$

The charge controller or regulator is required to charge the batteries and to maintain the long life of the battery bank. The regulators function is to carry $5.80 \mathrm{~A}$ of short-circuit current from the PV panels $\left(I_{\mathrm{psc}}\right)$. In this study, a maximum current charge controller $\left(I_{\mathrm{pvc}}\right)$ of $60 \mathrm{~A}$ is selected maintaining a constant DC voltage of $24 \mathrm{~V}$. In order to confirm and ensure that an appropriate regulator has been selected; the product of $I_{\mathrm{psc}}, M_{\mathrm{p}}$, and a factor of $125 \%$ [15] has to be equal to or not higher than $I_{\mathrm{pvc}}$ (9). For this case study, a total value of 45.96 was achieved, thus, performing under the limits of the charge controller carefully chosen $(45.96 \leq 60 \mathrm{~A})$ :

$$
I_{\mathrm{psc}} * M_{\mathrm{p}} * 125 \% \leq I_{\mathrm{pvc}} .
$$

The rated power of the inverter $\left(P_{\text {inv-rated }}\right)$ is taken to be at least $20 \%$ higher than the appliances power $\left(P_{\text {rated }}\right)$ [5]. The specifications for the required inverter are $2.4 \mathrm{~kW}\left(P_{\text {inv }}\right)$, 24 volts DC, frequency of $50 \mathrm{~Hz}$, and a loss of coefficient produced by the inverter $\left(k_{c}\right)$, running at optimum service taken to be 0.05 . In addition, to make sure that a satisfactory inverter has been selected, $P_{\text {inv-rated }}(10)$ must be equal to or not higher than $P_{\text {inv }}$. When inverters are first turned on current flows are produced, exceeding the steady-state current value within a typical range from 3 to 6 times. This effect is known as In-Rush Current [16]; for this case it has been selected as 3:

$$
P_{\text {inv-rated }}=\left[\left(\frac{P_{\text {rated }}}{\left(1-k_{c}\right)}\right) *(\text { In-Rush Current })\right] .
$$

As a result, the power of the required inverter is higher than or equal to $2.141 \mathrm{~kW}$ ( $\left.P_{\text {inv-rated }}\right)$, confirming the selected inverter as the appropriate to perform in the system $(2.141 \mathrm{~kW}$ $\leq 2.4 \mathrm{~kW}$ ). Table 2 represents a summary of the solar PV components selected in the design for this study.

6.2. System Simulation: PVSyst. The software PVSyst [17] was used in this study, in order to validate the design and data analysis of the PV system. The simulation dealt with the stand-alone system, including meteorological data, components of the system, and the solar energy tools. To simulate the system before, the daily energy consumption of an urban house was required and determined according to the minimum load requirements (Table 1).

The daily energy consumed was designed to be $3.332 \mathrm{kWh} /$ day constantly, over the course of a year. Thus, the same parameters for the electrical demand have been introduced for the simulation.

6.2.1. Preliminary Design Input Data Procedure. The initial presizing was carried out, in order to give an estimation of the features of a PV system. The software carried out an evaluation of the systems yield in monthly values using the general parameters, without specifying the components of the system. The first step in the preliminary design was to specify the type of system (grid-connected, stand-alone, or pumping system). In this study, a stand-alone system was considered.

The next step involved choosing the site. Banjul was not available in the geographical site of the database software; hence, the location and meteorological data was imported from the RET Screen International software [18] with the purpose of obtaining the site parameters as shown in Table 3.

Once the meteorological data was imported monthly meteorological calculations were carried out, in order to determine the horizon and sun path diagrams for Banjul. The 
TABLE 2: Solar PV system components.

\begin{tabular}{|c|c|c|c|}
\hline Items & Quantity & Manufacturer model & Characteristics \\
\hline PV panel & 3 & Auversun, AV275M96NB-5P & $\begin{array}{c}P_{\text {nom }}=0.275 \mathrm{~kW}_{\mathrm{p}} \\
G=1000 \mathrm{~W} / \mathrm{m}^{2} \\
\mathrm{AM}=1.5 \\
V_{\text {rated }}=51.2 \mathrm{~V}\end{array}$ \\
\hline Charge controller & 1 & Morningstar, Tristar TS MPPT 60 A-24 V & $\begin{array}{c}V=24 \mathrm{~V} \\
I_{\max }=60 \mathrm{~A}\end{array}$ \\
\hline Inverter & 1 & Sun Power, PVUP 3000 & $\begin{array}{c}P_{\text {nom }}=2.4 \mathrm{~kW} \\
V_{\text {nom }}=230 \mathrm{~V} \\
\text { Freq }=50 \mathrm{~Hz} \\
\text { Eff }=90 \%\end{array}$ \\
\hline Battery & 7 & Concorde, PVX-2580L & $\begin{array}{c}C_{\text {nom }}=239 \mathrm{Ah} \\
V_{\text {nom }}=12 \mathrm{~V} \\
\mathrm{Eff}=97 \%\end{array}$ \\
\hline
\end{tabular}

TABLE 3: Monthly meteorological data imported to the PVSyst [18].

\begin{tabular}{lcccc}
\hline Months & $\begin{array}{c}\text { Global irradiation } \\
\left(\mathrm{kWh} / \mathrm{m}^{2} / \mathrm{month}\right)\end{array}$ & $\begin{array}{c}\text { Diffuse irradiation } \\
\left(\mathrm{kWh} / \mathrm{m}^{2} / \mathrm{month}\right)\end{array}$ & $\begin{array}{c}\text { Ambient temperature } \\
(\mathrm{C})\end{array}$ & Wind velocity (m/s) \\
\hline January & 161.8 & 51.4 & 26.0 & 3.7 \\
February & 160.7 & 55.7 & 27.1 & 4.0 \\
March & 205.2 & 58.1 & 28.7 & 4.3 \\
April & 212.1 & 52.1 & 28.4 & 4.4 \\
May & 199.6 & 64.1 & 27.7 & 4.2 \\
June & 174.6 & 63.7 & 26.5 & 4.0 \\
July & 169.9 & 69.2 & 26.1 & 3.1 \\
August & 166.2 & 78.5 & 26.2 & 2.8 \\
September & 163.8 & 77.0 & 27.5 & 2.4 \\
October & 170.2 & 69.8 & 29.2 & 2.3 \\
November & 159.9 & 49.2 & 27.3 & 4.0 \\
December & 152.5 & 50.5 & 27.3 & 4.3 \\
Year & 2056.5 & 739.4 & & 3.4 \\
\hline
\end{tabular}

optimum angle of inclination for a fixed tilt collector in a stand-alone system maximizes the daily irradiation during the worst month. In this case, the worth month is December with the least irradiation of $4.92 \mathrm{kWh} / \mathrm{m}^{2} /$ day. Therefore, a tilt angle of $41^{\circ}$ was also selected.

The final step was to verify and confirm the system parameters:

(i) Battery and system voltage, $24 \mathrm{~V}$, was considered.

(ii) Number of days of autonomy $(N)$ is the consecutive days without sunshine, to define the capacity of the battery bank. For this study, 3 days were considered.

(iii) Loss of Load Probability (LOLP) is the fraction of time where the electricity is not available during the time it is required. A LOLP of $5 \%$ was considered.

6.2.2. Preliminary Design Input Data Procedure. The aim of designing the system with PVSyst was performed using detailed monthly simulation. The simulation procedure was achieved as shown in Figure 7.

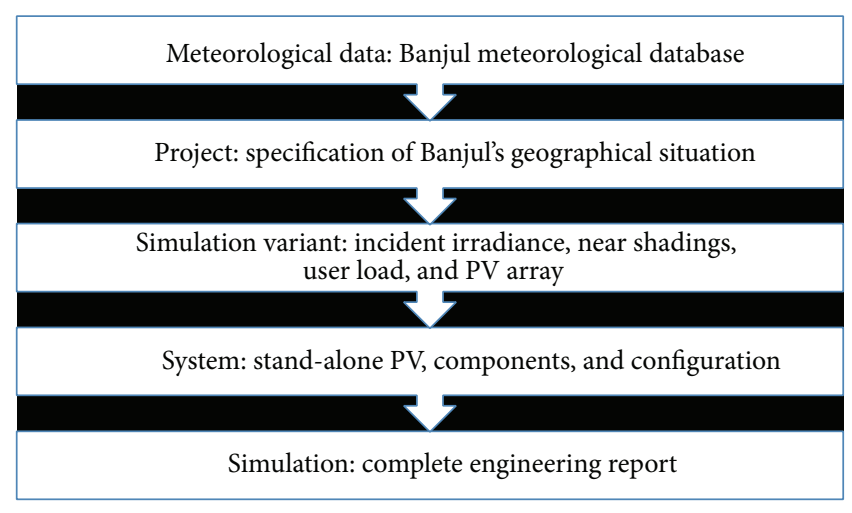

FIgURE 7: Outline of simulation process.

Initially, the input data included details of location, solar irradiance, and name of the project. Consequently, the feeding of the values was accomplished; the Albedo values were considered as a default of 0.20. Albedo values are 


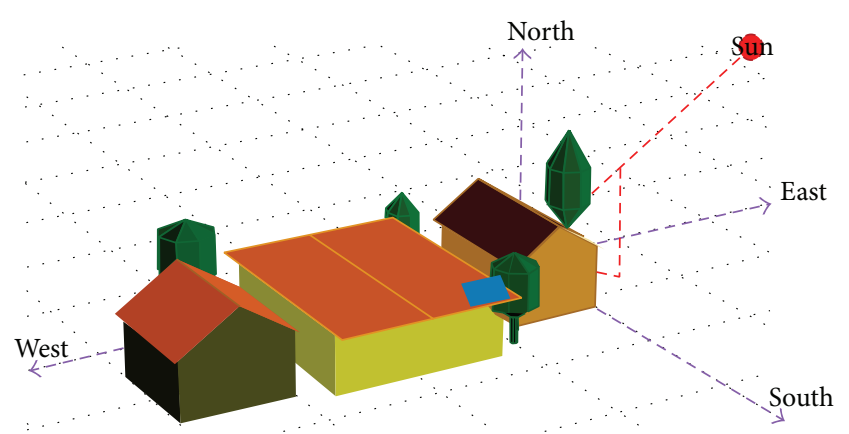

FIGURE 8: South facing PV array and its environment in Banjul.

the reflecting power of the surface of a location, from the irradiance of the sunlight.

As it had been set in the preliminary design, the PV modules are on a fixed tilted plane, with an angle of $41^{\circ}$. The azimuth angle was $0^{\circ}$ for the location of the sun on the east-west axis. A fixed tilted plane was designed for this study, since the system was optimized for lower monthly radiation. The properties of the system were defined as the third step. The definition of the parameters depends on the type of components necessary to achieve the load requirements for the households. The components were defined according to Table 2 .

It was not possible to reconstruct the structure of the house with a computer aided design software such as Sketchup to introduce the 3D shading scenes. Therefore, the near shadings by trees and other buildings were not considered as part of the simulation. Figure 8 represents the reconstruction of the house modelled in PVSyst.

The simulation process involved the available variables in monthly tables and graphs. The data of interest was defined before the simulation, in order to be collected in hourly or daily values. The software offered three methods for the output of the data: (a) accumulating hourly values; (b) ASCII export files; and (c) special graphs.

After the simulation, as a final step, the results dialogue was made available, in order to obtain a printable report. The report included all the parameters used during the simulation, together with a description of the results.

\section{Results and Discussions}

The simulation engine used random daily data, in order to obtain real weather characteristics. The energy exported on a daily basis varies from day to day with different seasonal patterns. Figure 9 represents that the output energy is lower between June and October compared with the rest of the year, due to the losses produced by the rainfall during the wet season (June to October). In addition, the array output resulted in a reverse "Weibull curve" with high values of power generated between 250 and $350 \mathrm{~W}$ as shown in Figure 10. The energy production ceases above $550 \mathrm{~W}$, due to the constant operation of the array at temperatures above the Standard Test Condition (STC).

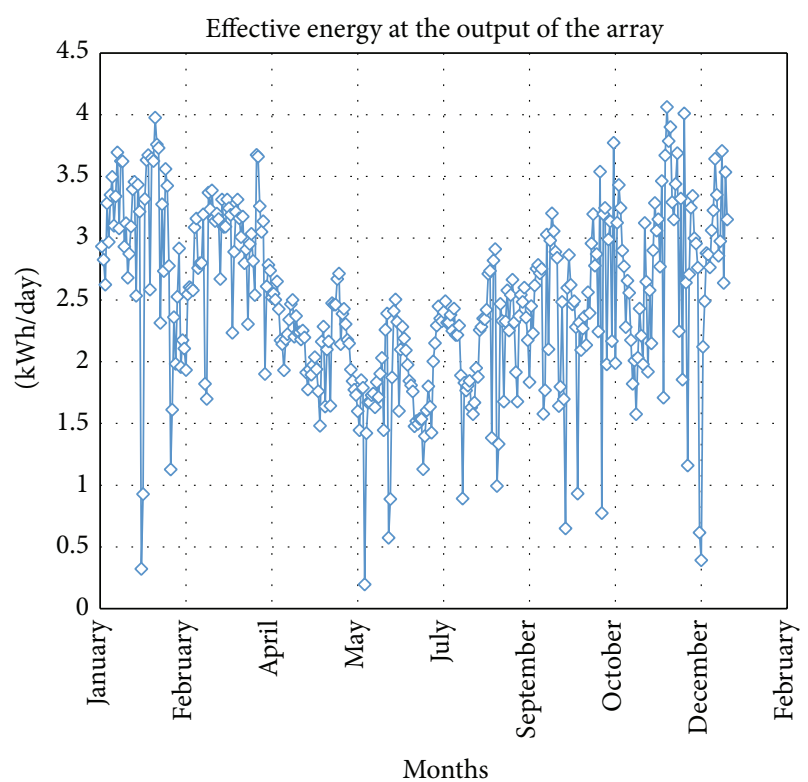

FigURE 9: Daily array output energy.

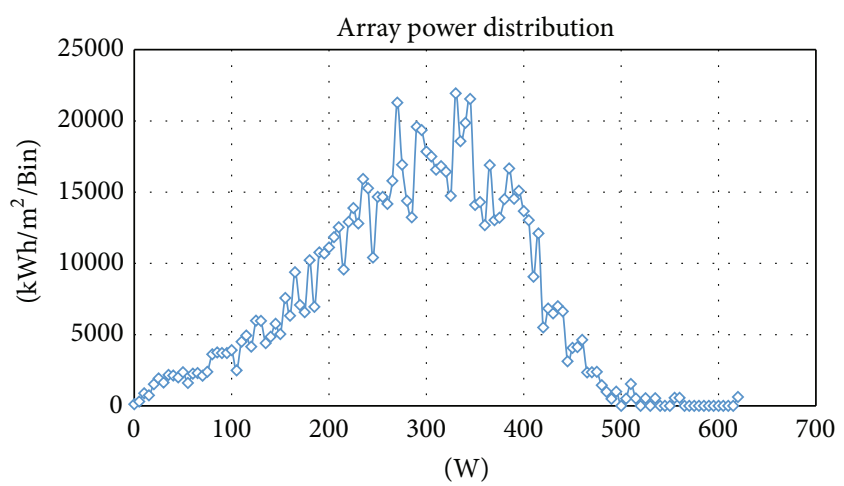

Figure 10: Array power distribution.

In Banjul, the highest temperatures are in November with an average of $29^{\circ} \mathrm{C}$; thus, this affects the operating temperatures of the PV array during the year as shown in Figure 11. It is ascertained that high temperatures will significantly affect the open-circuit voltage and, hence, the power that the PV array can deliver [19].

A yearly average performance ratio (PR) of 0.526 was observed in Figure 12, with the maximum in January. A low $\mathrm{PR}$ was obtained in the month of June due to the temperature derating through the hot and humid summer. Likewise, the solar fraction (SF), which is the fraction of the solar energy available $\left(E_{\text {sol }}\right)$ and the energy needed for the user $\left(E_{\text {load }}\right)$, was found to be 0.696 over the course of the year. PR values lower than $75 \%$ should be investigated according to $[20,21]$. The analysis has shown that the performance depends on the components efficiency, their design, and load configuration. The PR alone cannot describe the operation of the SSPVS from a technical point of view; therefore, a more detailed analysis in terms of the system operation will require detailed and reliable monitoring devices, studies on the evolution of 


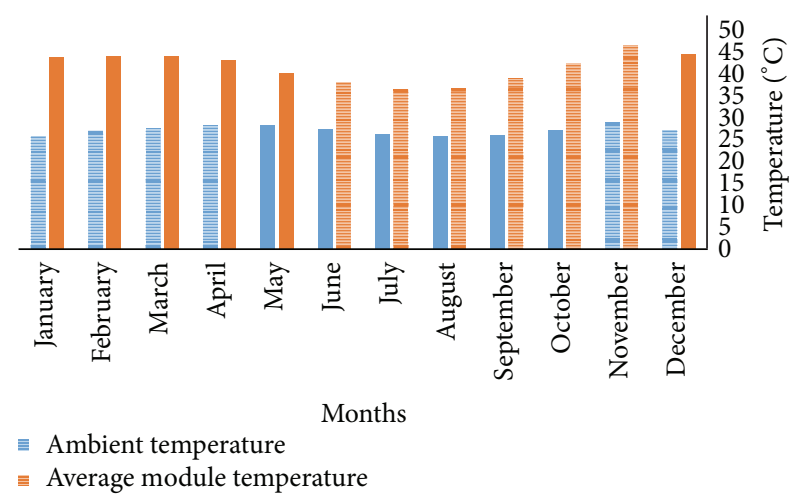

Figure 11: Ambient temperature versus average module temperature.

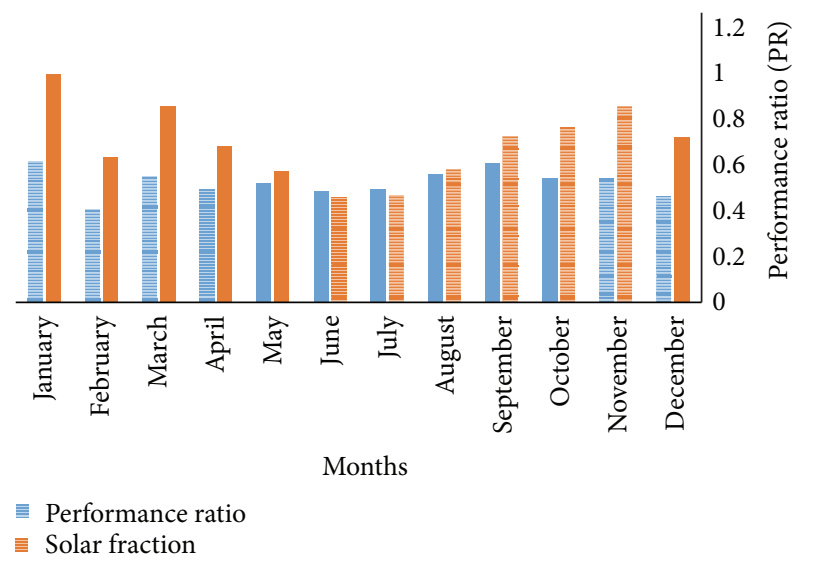

FIGURE 12: Performance ratio and solar fraction.

the user behavior over time, or the use of advanced simulation tools to evaluate the influence of component sizes.

Figure 13 illustrates the SSPVS energy losses, where a 7\% loss is produced from converting the horizontal irradiation to the global irradiation incident. Furthermore, the large loss of $9.2 \%$ is caused by the temperature derating effect (hot and humid summer), with converter losses at $4.9 \%$ and $0 \%$ shading losses. The rest of the losses are attributable to the Incidence Angle Modifier (IAM), module array mismatch losses at $1.9 \%$, model quality losses at $2 \%$, and cable losses at $3.1 \%$. The irradiance level losses of $3.4 \%$ are due to the low irradiance and high STC irradiance levels.

\section{Economic Analysis}

8.1. Life Cycle Cost Analysis. In this section, the estimation of the life cycle cost $\left(\mathrm{L}_{\mathrm{cc}}\right)$ is discussed. A high initial cost is essential, but the advantages are that the maintenance cost is low, and there are no fuel costs as using diesel generators. The expenditure for the system, including the purchasing and replacement costs, is represented with the corresponding currency rates in Table 4.

The life time $(N)$ of all the items, excluding the battery bank, is considered to be approximately 20 years. The batteries selected for this project are lead-acid vented tubular and
TABLE 4: Costs of all items [16, 17].

\begin{tabular}{|c|c|c|}
\hline Items & $\begin{array}{c}\text { Cost } \\
\text { (Pound Sterling) } \\
\end{array}$ & $\begin{array}{c}\text { Cost } \\
\text { (Gambian Dalasi) }\end{array}$ \\
\hline PV panel & $£ 0.41 / \mathrm{W}_{\mathrm{p}}$ & GMD27.48/W \\
\hline Battery & $£ 0.53 / \mathrm{Ah}$ & GMD35.54/Ah \\
\hline Charge controller & $£ 2.65 / \mathrm{A}$ & GMD177.72/A \\
\hline Inverter & $£ 0.18 / \mathrm{W}$ & GMD12.16/W \\
\hline Installation & \multicolumn{2}{|c|}{$10 \%$ of PV panel cost } \\
\hline Maintenance/year & \multicolumn{2}{|c|}{$2 \%$ of PV panel cost } \\
\hline
\end{tabular}

TABLE 5: Total cost of items $[16,17,19]$.

\begin{tabular}{lc}
\hline Items & Cost $\left(C_{\text {it }}\right)$ \\
\hline $\begin{array}{l}\text { Cost of the PV panel }\left(C_{\mathrm{PVp}}\right) \\
\text { Initial cost of the batteries }\end{array}$ & $\left(3 * 0.275 \mathrm{~kW}_{\mathrm{p}}\right) * £ 0.41=£ 338.25$ \\
$\left(C_{b}\right)$ & $£ 2.65 * 60 \mathrm{~A}=£ 159$ \\
$\begin{array}{l}\text { Cost of the charge } \\
\text { controller }\left(C_{c}\right)\end{array}$ & $£ 0.18 * 2.4 \mathrm{~kW}=£ 432$ \\
Cost of the inverter $\left(C_{\text {inv }}\right)$ & $10 \% * £ 338.25=£ 33.82$ \\
$\begin{array}{l}\text { Installation costs }\left(C_{\text {inst }}\right) \\
\text { Maintenance cost per year } \\
(\mathrm{M} / \mathrm{yr})\end{array}$ & $2 \% * £ 338.25=£ 6.76$
\end{tabular}

they do not require maintenance; consequently, they have a life span of roughly 10 years. Therefore, a group of 7 batteries has to be purchased after 10 and 20 years. According to the "Gambia Mineral \& Mining Sector Investment and Business Guide," the country's inflation rate $(i)$ is $6 \%$, with a discount rate $(d)$ of $10 \%$ [22]. Consequently, the total cost of all items $\left(C_{\mathrm{it}}\right)$ based on the data collected in Table 4 can be calculated as shown in Table 5 [23].

The 1st battery group $\left(C_{b 1}\right)$ purchased after 10 years $\left(N_{1}\right)$ can be calculated to be $£ 612.21$, and consequently a 2 nd $\left(C_{b 2}\right)$ group of batteries to be purchased after 20 years $\left(\mathrm{N}_{2}\right)$ can be calculated to be $£ 422.70$ using the following equation:

$$
C_{b 1, b 2, \ldots, b n}=\left[C_{b} *\left(\frac{(1+i)}{(1+d)}\right)^{N_{1,2, \ldots, n}}\right] .
$$

The total annual maintenance costs $\left(C_{\mathrm{M} / \mathrm{yr}}\right)$ over the life time of 20 years $(N)$ can be calculated to be $£ 93.69 \approx £ 93.70$ using the maintenance cost per year $(\mathrm{M} / \mathrm{yr})$ with the following equation [24]:

$$
\begin{aligned}
C_{\mathrm{M} / \mathrm{yr}}= & (\mathrm{M} / \mathrm{yr}) *\left(\frac{1+i}{1+d}\right) \\
& *\left[\frac{1-((1+i) /(1+d))^{N}}{1-((1+i) /(1+d))}\right] .
\end{aligned}
$$

Therefore, $\mathrm{L}_{\mathrm{cc}}$ of the system is calculated to be $£ 2977.43$ from the following equation:

$$
\begin{aligned}
\mathrm{L}_{\mathrm{cc}} & =\left(C_{\mathrm{PVp}}+C_{b}+C_{b 1}+C_{b 2}+C_{c}+C_{\mathrm{inv}}+C_{\text {inst }}\right. \\
& \left.+C_{\mathrm{M} / \mathrm{yr}}\right) .
\end{aligned}
$$




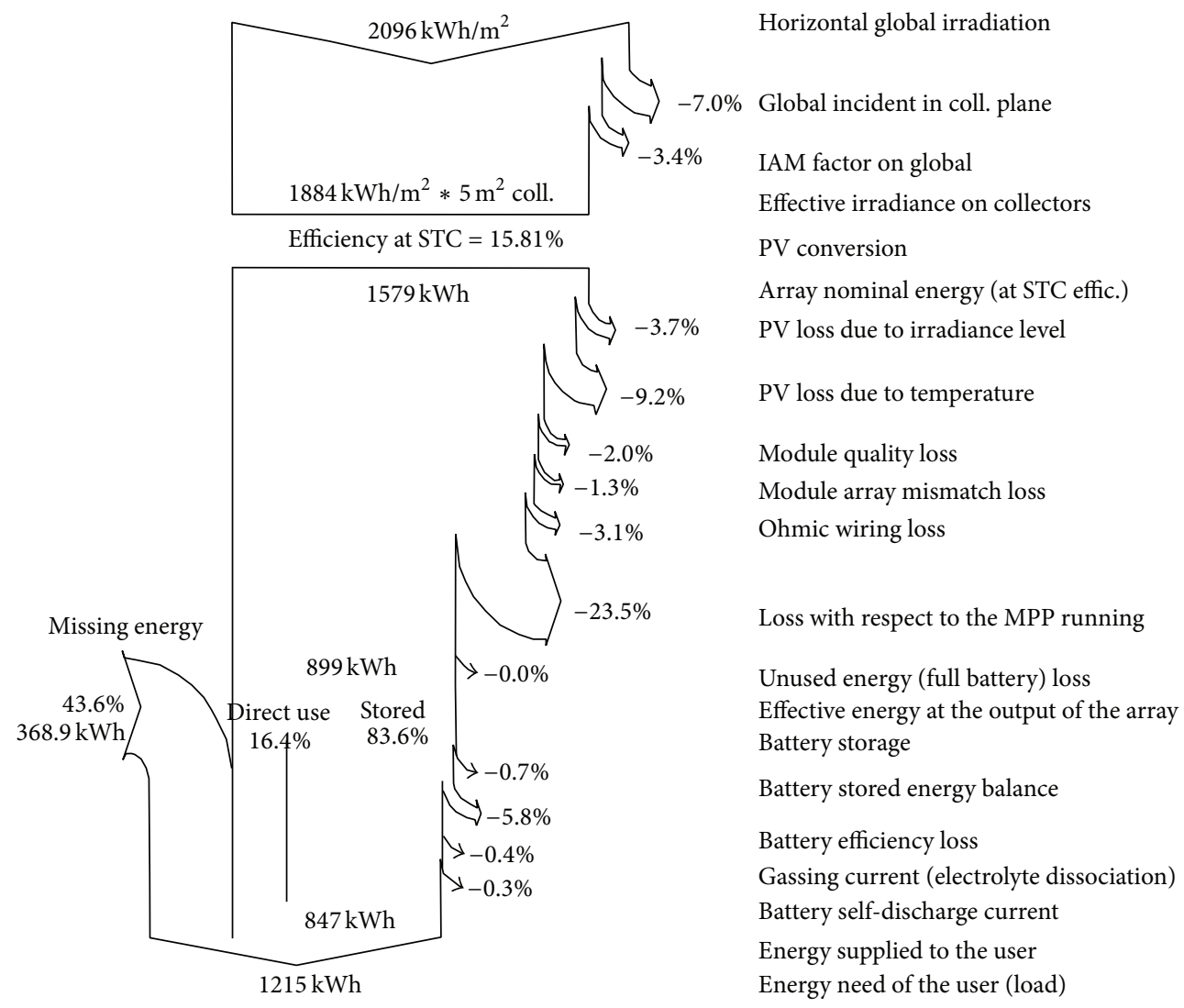

Figure 13: Energy losses diagram.

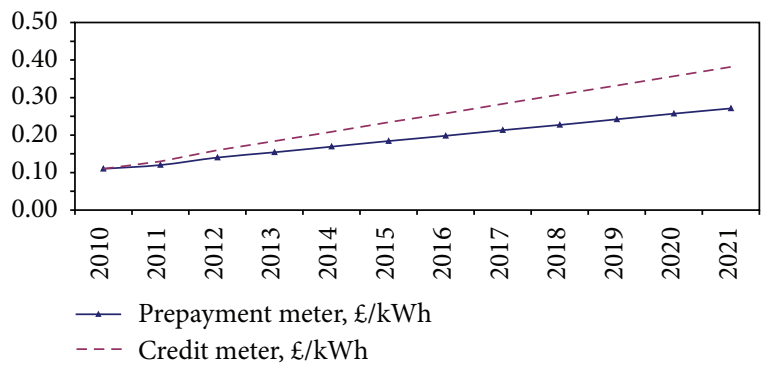

Figure 14: Projected NAWEC utility prices (2012-2021).

In order to calculate the unit electrical cost of $1 \mathrm{kWh}$, it is necessary to calculate $\mathrm{L}_{c c}$ of the system on an annual basis. Hence, the annual life cycle cost $\left(\mathrm{AL}_{\mathrm{cc}}\right)$ of the SSPVS can be calculated to be $£ 206.67$, from [24]

$$
\mathrm{AL}_{\mathrm{cc}}=\mathrm{L}_{\mathrm{cc}} *\left[\frac{1-((1+i) /(1+d))}{1-((1+i) /(1+d))^{N}}\right] \text {. }
$$

Finally, once annual life cycle cost $\left(\mathrm{AL}_{\mathrm{cc}}\right)$ is calculated, the unit electrical cost can be calculated to be $£ 0.169 / \mathrm{kWh} \approx$ $0.170 / \mathrm{kWh}$ using

$$
\text { Unit electrical cost }=\frac{\mathrm{AL}_{\mathrm{cc}}}{E_{d^{\prime}} * 365} .
$$

Solar PV system installers are encouraged to sell the electricity of the PV system at a price not lower than $£ 0.170 / \mathrm{kWh}$, in order to maximize their profit. In 2010, NAWEC was offering a domestic utility tariff of $£ 0.110 / \mathrm{kWh}$ for prepayment and credit meters; however, in a short period there was a price rice of 3\% and two years later up to 5\% [25]. Figure 14 represents a projected graph of the domestic utility prices from 2010 to 2021 if the energy prices continue rising. The results show that, in 2021, the prepayment meter and credit meter might increase for about $0.27 \mathfrak{E} / \mathrm{kWh}$ and $0.38 \mathfrak{k} / \mathrm{kWh}$, respectively.

\section{Conclusion}

Gambia is currently in a challenging situation, with a large number of its citizens unable to access electricity in their daily lives. Network infrastructures are still underdeveloped and there is a general lack of detailed data on their deployment and, in addition, the expansion plans. A complete computer simulation was undertaken to study the performance of an SSPVS in a domestic house in Banjul. The purpose of the simulation was described with a methodology in detail and involved research for data collection and an investigation into the location. The manual system sizing and design made by the simulation engine had very accurate results, as the quantity of components required to supply power from the SSPVS has all matched, except the number of batteries (7 for the manual sizing and 8 from PVSyst). 
The simulations have demonstrated the efficiency of the model, performance of the components, and production of the system's results, although the software lacks the facility of importing 3D models as presented in Section 4 using Sketchup Pro 8, which limits the capability of PVSyst. A model import function would permit the importation of proposed buildings into PVSyst for a better optimisation and modelling.

The life cycle cost analysis analysis noted that in Gambia the price of using SSPVS is lower compared to the unit electricity price. This price is predicted to diminish in the future, if the initial cost of the PV modules decreases. Meanwhile, if the unit cost of electricity grows to be three times its current value, due to an increase in fuel prices [3], the demand for solar PV systems for use in domestic housing will increase. The results of the $\mathrm{L}_{\mathrm{cc}}$ study demonstrated that electrifying a domestic house is favourable and suitable with regard to long term investment, as the prices of the PV system components continue to reduce. Likewise, they represent a vital, efficient, and economical alternative resource to diesel generators $[3,4]$.

\section{Conflict of Interests}

The authors declare that there is no conflict of interests regarding the publication of this paper.

\section{Acknowledgments}

The authors would like to thank Toshiba Research Europe (TRE), the Engineering and Physical Sciences Research Council (EPSRC), and Cardiff University for their technical and financial support.

\section{References}

[1] E. S. Sanneh and A. H. Hu, "Lighting rural and peri-urban homes of the gambia using solar photo-voltaics (PV)," Open Renewable Energy Journal, vol. 2, no. 1, pp. 1-13, 2009.

[2] The Encyclopedia of the Nations, "Average Duration of Power Outages (hours)-Enterprise Survey Indicators, Country Comparison, Nations Statistics," November 2014, http://www .nationsencyclopedia.com/WorldStats/ESI-average-durationpower-outages.html.

[3] Lahmeyer International GmbH, Renewable Energy Master Plan for the Gambia, Lahmeyer International GmbH, 2006.

[4] Access Gambia, Gambia Electrical Blackouts, 2014, http://www .accessgambia.com/information/power-outages.html.

[5] J. V. Roger and A. Messenger, Photovoltaic Systems Engineering, vol. 40, CRC Press, Boca Raton, Fla, USA, 2nd edition, 2001.

[6] Lahmeyer International GmbH, Feasibility Study Solar Home System Program, the Gambia, Energy Division, Office of the President, Banjul, Gambia, 2006.

[7] United Nations Development Programme (UNDP), "Human development reports," Tech. Rep., 2008, http://hdr.undp.org/ en/media/HDI_2008_EN_Tables.pdf.

[8] Brufut Eduction, "The Gambia-The Brufut Education Project," 2007, http://brufuteducationproject.com/the-gambia/.
[9] Lahmeyer International GmbH, Energy Study Draft RE Master Plan-Module I. Energy Demand Assessment and Projection, Lahmeyer International GmbH, Bad Vilbel, Germany, 2005.

[10] S. Kinteh, "Report of a National Household Energy," 2005.

[11] Last Software, "SketchUp Pro, SketchUp," October 2015, http:// www.sketchup.com/products/sketchup-pro.

[12] Concorde Battery Corporation, "Battery Sizing Tips for Stand Alone PV Systems," 2009, http://www.concordebattery.com/.

[13] A. D. Jones and C. P. Underwood, "A thermal model for photovoltaic systems," Solar Energy, vol. 70, no. 4, pp. 349-359, 2001.

[14] M. Arif and M. E. Khan, "Design and life cycle cost analysis of a SAPV system to electrify a rural area household in India," Current World Environment, vol. 5, no. 1, pp. 101-106, 2010.

[15] National Electrical Code Committee, "Conductor sizing and over currents protection," in National Electrical Code, vol. 14, pp. 154-175, National Electrical Code Committee, McIntosh, Ala, USA, 2014.

[16] Internationational Electrotechnical Commission, Internationational Electrotechnical Commission, IEC 61000-4-30, Electromagnetic Compatibility (EMC), 2003.

[17] Rets. I. Government of Canada, Natural Resources Canada, Energy Sector, CANMET Energy Technology Centre-Varennes, "RETScreen International Climate data", http://www.retscreen.net/ang/d_data_w.php.

[18] N. R. C. E. S. C. E. T. C.-V. Rets. I.Government of Canada, "RETScreen International Climate data".

[19] S. Dubey, J. N. Sarvaiya, and B. Seshadri, “Temperature dependent photovoltaic (PV) efficiency and its effect on pv production in the world-a review," Energy Procedia, vol. 33, pp. 311-321, 2013.

[20] D. Mayer and M. Heidenreich, "Performance analysis of stand alone PV systems from a rational use of energy point of view," in Proceedings of the $3 r d$ World Conference on Photovoltaic Energy Conversion, vol. 3, pp. 2155-2158, IEEE, Osaka, Japan, May 2003.

[21] W. G. J. H. M. Van Sark, N. H. Reich, B. Müller, A. Armbruster, K. Kiefer, and C. Reise, "Review of PV performance ratio development," in Proceedings of the World Renewable Energy Forum (WREF '12), vol. 6, pp. 4795-4800, American Solar Energy Society, Denver, Colo, USA, May 2012.

[22] USA International Business Publications, Gambia Mineral \& Mining Sector Investment and Business Guide, World Stra, 2007.

[23] P. Birajdar, S. Bammani, A. Shete, R. Bhandari, and S. Metan, "Assessing the technical and economic feasibility of a standalone PV system for rural electrification: a case study," International Journal of Engineering and Research Applications, vol. 3, no. 4, pp. 2525-2529, 2013.

[24] T. Markvart, Solar Electricity, John Wiley \& Sons, 2000.

[25] Nawec, "National Water and Electricity Company-Utility Tariff," 2012, http://www.nawec.gm/index.php/faqs/tariff. 


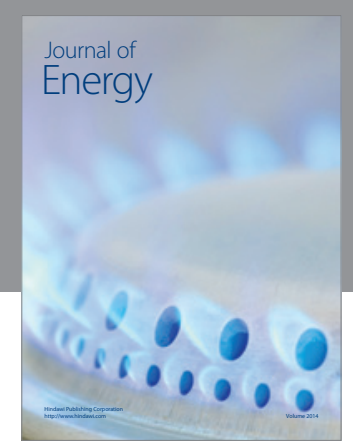

Journal of

Industrial Engineering
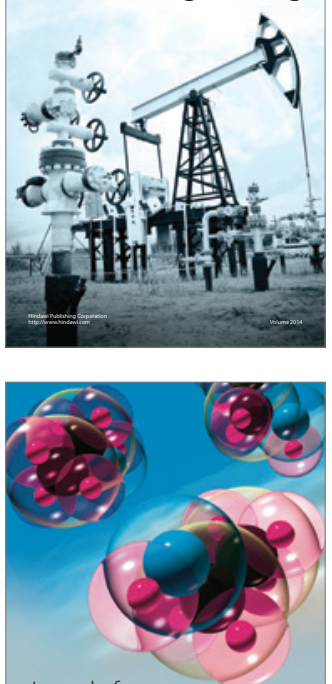

Fuels
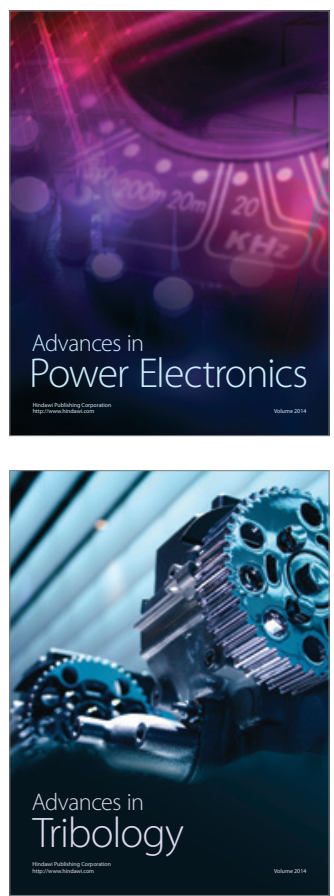

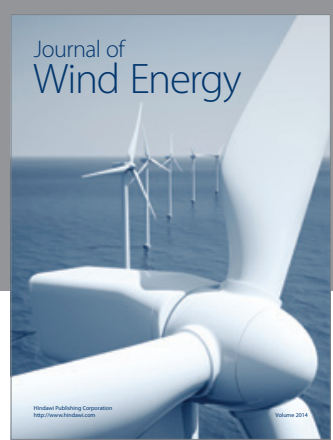

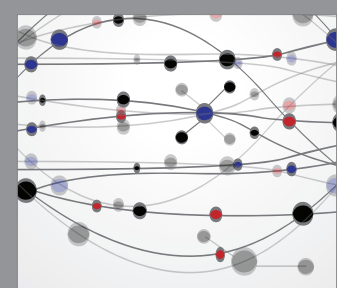

The Scientific World Journal

Submit your manuscripts at http://www.hindawi.com

Journal of

Structures
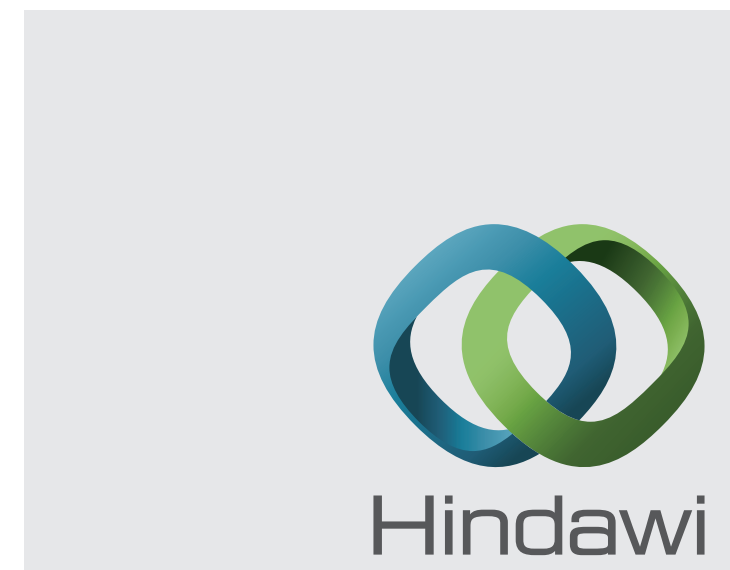

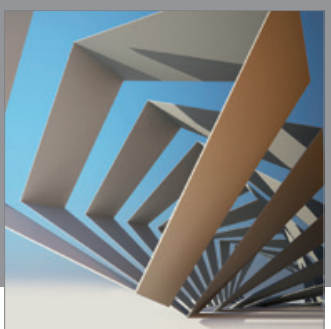

Rotating

Machinery
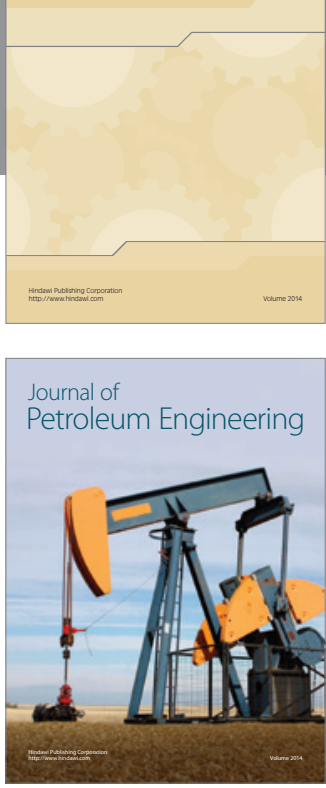

Journal of

Solar Energy
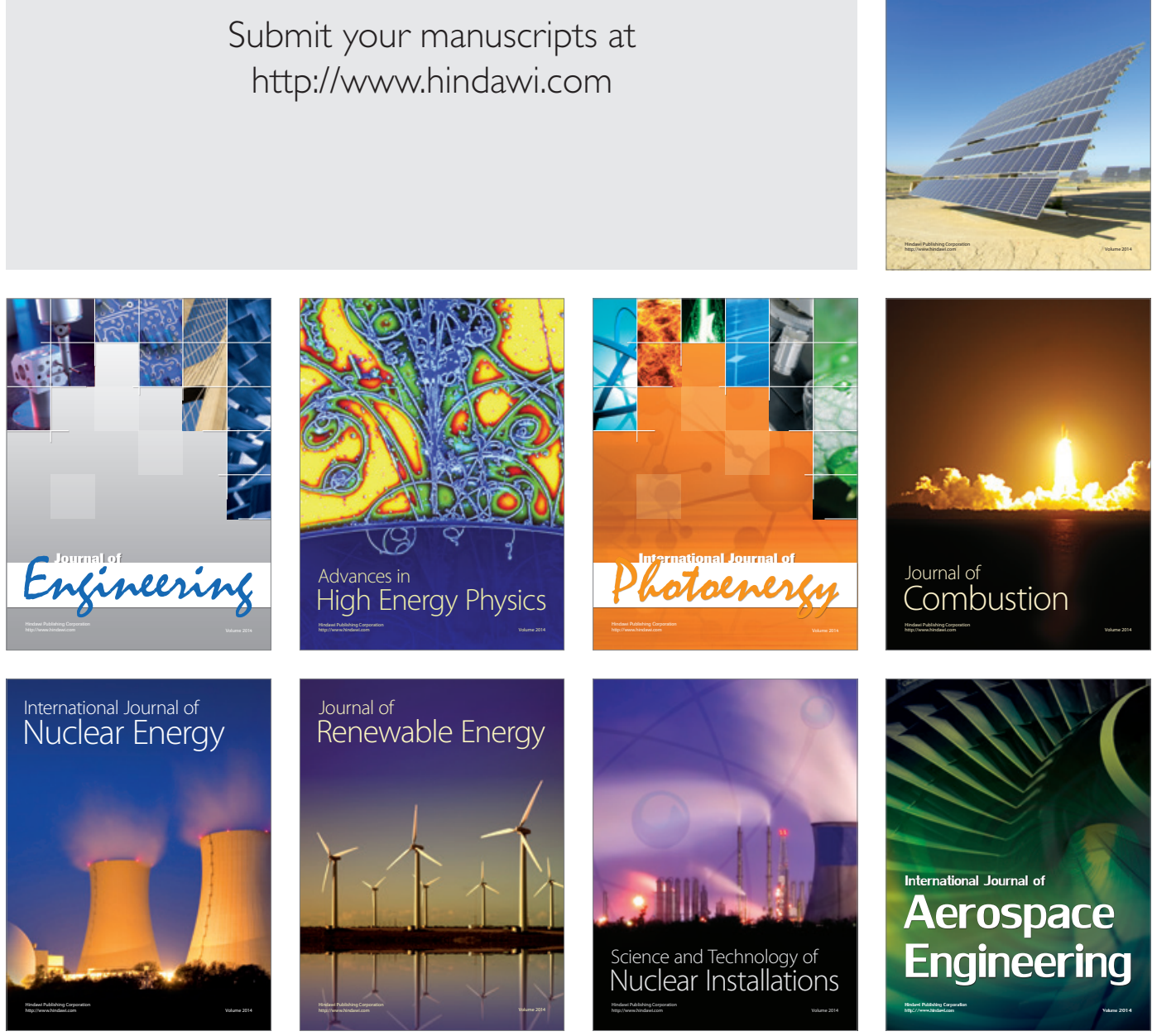